\title{
Elevated Concentrations of Dietarily-Important Trace Elements and Macronutrients in Edible Leaves and Grain of 27 Cowpea (Vigna unguiculata L. Walp.) Genotypes: Implications for Human Nutrition and Health
}

\author{
Alphonsus K. Belane ${ }^{1}$, Felix D. Dakora ${ }^{2}$ \\ ${ }^{1}$ Department of Crop Science, Tshwane University of Technology, Pretoria, South Africa; ${ }^{2}$ Department of Chemistry, Tshwane Uni- \\ versity of Technology, Pretoria, South Africa. \\ Email: DakoraFD@tut.ac.za
}

Received October 21 $1^{\text {st }}, 2011$; revised December $12^{\text {th }}, 2011$; accepted December $19^{\text {th }}, 2011$

\begin{abstract}
Legumes are a good source of calories, protein and mineral nutrients for human nutrition and health. In this study, the edible leaves and grain of 27 field-grown cowpea genotypes were assessed for trace elements and macronutrient density at Manga in the Sudano-Sahelian zone of Ghana in 2005 and 2006, using inductively coupled plasma-mass spectrometry. The genotypes differed markedly in their accumulation of trace elements and major nutrients in edible leaves and grain. Except for $\mathrm{P}$, the concentrations of $\mathrm{K}, \mathrm{Ca}, \mathrm{Mg}, \mathrm{S}$ and $\mathrm{Na}$ were much higher in edible cowpea leaves than grain in 2005. A similar pattern was observed for $\mathrm{Ca}, \mathrm{Mg}, \mathrm{S}, \mathrm{Na}$ in 2006. However, more dramatic variations were found in the micronutrient concentrations between edible cowpea leaves and grain. The levels of the trace elements $\mathrm{Fe}, \mathrm{Cu}, \mathrm{Zn}, \mathrm{Mn}$ and B were sometimes 2- to 20-fold greater in leaves than grain of cowpea. Furthermore, there were strong geno- typic differences in mineral density of cowpea leaves and grain. For the major nutrients, for example, IT93K-2045-29 and IT90K-59 accumulated greater concentrations of $\mathrm{P}, \mathrm{K}, \mathrm{Ca}, \mathrm{S}$ and $\mathrm{Na}$ in both edible leaves and grain in 2006, while ITH98-46, which showed the least macronutrient density, exhibited the highest concentrations of $\mathrm{Fe}, \mathrm{Zn}, \mathrm{Cu}, \mathrm{Mn}$ and $\mathrm{B}$ in edible leaves, as well as $\mathrm{Fe}, \mathrm{Cu}$ and $\mathrm{Mn}$ in grain. These results have implications for cowpea breeding, as well as for human nutrition and health.
\end{abstract}

Keywords: Calories; Protein; Trace Elements; Macronutrients; Nutrition; Ontogeny

\section{Introduction}

African soils are generally nutrient-poor [1-3] and thus produce food crops that are also deficient in mineral nutrients (especially trace elements) for human nutrition and health. As a result, micronutrient deficiency is very prevalent among rural African children who depend on locally-produced, low-nutrient grain and vegetable foods as sources of essential dietary minerals. Micronutrient deficiency in children is equally a major health problem in South Africa [4-7], and government has resorted to exogenous supplementation of food materials with vitamins and trace elements such as $\mathrm{Se}, \mathrm{Fe}$ and $\mathrm{Zn}$ in order to overcome micronutrient deficiency. Elsewhere in the world, a different approach has been used, and this involves the selection of plant species and genotypes with the ability to increase micronutrient uptake and accumulation in edible plant parts [8-10]. There are also reports of genetic manipulation of crop plant species for improved micronutrient capture from soil $[8,11]$. In that regard, symbiotic legumes are generally more efficient at taking up mineral nutrients (including trace elements) than cereal crops [12-15]. As a result, the increased consumption of legume-based diets could prove to be a better option for overcoming micronutrient deficiency in Africa, provided these foods are low in anti-nutritional factors such as phytate and polyphenols, and therefore, readily bioavailable [16-19]. Cowpea is the most important food legume in Africa. Both its leaves and grain are eaten as source of calories and dietary protein. So far, however, very scanty information is available on the concentration of mineral nutrients in edible parts of the cowpea plant. The aim of this study was 1) to assess 27 cowpea genotypes for concentration of trace elements and macronutrients in edible leaves and grain; 2) compare the mineral density of cowpea leaves at flowering and close to physiological maturity; and 3) compare edible cowpea leaves and grain as sources of dietary trace elements and macronutrients. 


\section{Methods and Materials}

\subsection{Site Description}

The experiment was conducted at the Savanna Agricultural Research Institute (SARI) at Manga, located in the Sudano-sahelian savanna (lat $11^{\circ} 11^{\prime} \mathrm{N}$ and long $0^{\circ} 61^{\prime} \mathrm{E}$ altitude $135 \mathrm{~m})$, with a unimodal rainfall $(800 \mathrm{~mm}$ annual mean) that starts in May/June and ends in September/ October. According to FAO (1990) [20], the soils at Manga are classified as Gleyic Alfisols with $\mathrm{pH} 6.0$ $\left(\mathrm{CaCl}_{2}\right)$, and contained $4.7 \mathrm{mg} \mathrm{P} / \mathrm{kg}, 20.3 \mathrm{mg} \mathrm{K} / \mathrm{kg}$, $0.38 \% \mathrm{C}, 0.07 \% \mathrm{~N}, 0.62 \%$ Organic matter content, and a $\mathrm{C}: \mathrm{N}$ ratio of 11.64 .

\subsection{Origin of Cowpea Genotypes}

The cowpea genotypes used for this study were a good mix of both breeder-improved cultivars and farmer selected varieties collected from Ghana, Tanzania, South Africa, and the International Institute of Tropical Agriculture (IITA) in Nigeria. The 27 genotypes exhibited different useful biological traits ranging from number of days to $50 \%$ flowering and number of days to physiological harvest, to levels of $\mathrm{N}_{2}$ fixation, pest resistance, and grain yield.

\subsection{Field Design and Planting}

A randomized complete block design was used with four replicate plots for each cowpea genotype in 2005 and 2006 experiments. The treatments consisted of 27 cowpea genotypes planted in plots measuring $3 \mathrm{~m} \times 5 \mathrm{~m}\left(15 \mathrm{~m}^{2}\right)$; with inter-row spacing of $60 \mathrm{~cm}$. Cowpea seeds were planted $20 \mathrm{~cm}$ apart within each row. Weeds were manually controlled with hand hoes.

\subsection{Plant Harvests and Processing}

Fully emerged young green trifoliate leaves were harvested from 12 plants per plot at 46 and 72 DAP in 2005 and 2006, respectively. The aim for harvesting cowpea leaves at 72 DAP in 2006 compared to 46 DAP in 2005 was to determine any changes in mineral density close to physiological maturity. Harvested leaves were ovendried $\left(60^{\circ} \mathrm{C}\right)$, weighed, and ground to fine powder $(0.85$ $\mathrm{mm})$ prior to analysis for mineral elements. Cowpea grain harvested at physiological maturity was similarly processed for elemental analysis.

\subsection{Mineral Nutrient Analysis}

To measure the $\mathrm{P}, \mathrm{K}, \mathrm{Ca}, \mathrm{Mg}, \mathrm{Cu}, \mathrm{Zn}, \mathrm{Mn}, \mathrm{Fe}$, and $\mathrm{B}$ in cowpea grain and leaves, $1 \mathrm{~g}$ of ground plant sample was ashed in a porcelain crucible at $500^{\circ} \mathrm{C}$ overnight. This was followed by dissolving the ash in $5 \mathrm{ml}$ of $6 \mathrm{M} \mathrm{HCl}$ (analytical grade) and placing it in an oven at $50^{\circ} \mathrm{C}$ for 30 min, after which $35 \mathrm{ml}$ of de-ionised water was added. The mixture was filtered through Whatman No. 1 filter paper. Mineral element concentration in plant extracts was determined from four replicate samples using inductively coupled plasma mass spectrometry (IRIS/AP HR DUO Themo Electron Corporation, Franklin, Massachusetts, USA) [21]. The quality of data collected was checked using standard solutions with certificates of analysis. In place of analyte isotopes to monitor each element, a known sample was used as standard after every 10 samples. Sulphur was determined by wet digestion procedure using 65\% nitric acid (high-purity grade). In each case, $1 \mathrm{~g}$ of milled plant material was digested overnight with $20 \mathrm{ml}$ of $65 \%$ nitric acid in a $250 \mathrm{ml}$ glass beaker. The beaker containing the extract was then placed on a sand bath and gently boiled until approximately $1 \mathrm{ml}$ of the extract was left. After that, $10 \mathrm{ml}$ of 4 $\mathrm{M}$ nitric acid (high-purity grade) was added and boiled for $10 \mathrm{~min}$. The beaker was removed from the sand bath, cooled, and the extract washed completely in a $100 \mathrm{ml}$ volumetric flask and filtered through Whatman No. 2 filterpaper. The $\mathrm{S}$ in the sample was then determined [22] FSSA, 1974) by direct aspiration on the calibrated ICPMS.

\subsection{Statistical Analysis}

The data on micro- and macro-nutrients in cowpea leaves and grain were subjected to analysis of variance (ANOVA) using a STATISTICA analytical software program version 7.1 [23]. A 2-way ANOVA was performed to compare means between cowpea leaves and grain, and 1-way ANOVA for comparing mineral nutrient levels among genotypes. Where significant differences were found, the Duncan Multiple Range Test (DMRT) was used to separate treatment means at $\mathrm{P} \leq 0.05$.

\section{Results}

\subsection{Trace Elements and Macronutrient Concentration in Edible Cowpea Leaves}

Analysis of edible cowpea leaves using inductively couple plasma mass spectrometry revealed significant differences among the 27 genotypes planted in the Sudano-sahelian savanna of Ghana in 2005. Cowpea genotypes such as Ngonji, Iron Grey, Brown Eye, Fahari and IT90K-76 exhibited the highest concentration of $\mathrm{P}$ in leaves, in contrast to Apagbaala and Pan 311, which showed the lowest $\mathrm{P}$ concentration (Table 1). Brown Eye, Glenda, IT90K-59, IT93K-2045-29, and Fahari also accumulated more $\mathrm{K}$ in leaves compared with the other genotypes, with CH14, Apagbaala, Pan 311, IT97K-499- 
Table 1. A comparison of macro-element density among genotypes and between edible leaves and grain of field cowpea grown at Manga, Ghana, in 2005. The leaves were sampled at 46 DAP and grain harvested at 76 DAP. Mean with dissimilar letters in a column for each genotype (lower case) and in row for each macronutrient (upper case) are significantly different at $P \leq$ 0.05. Coefficient of variation ranged from 1 to 34 .

\begin{tabular}{|c|c|c|c|c|c|c|c|c|c|c|c|c|}
\hline \multirow{2}{*}{ Genotype } & \multicolumn{2}{|c|}{$\mathrm{P}$} & \multicolumn{2}{|c|}{$\mathrm{K}$} & \multicolumn{2}{|c|}{$\mathrm{Ca}$} & \multicolumn{2}{|c|}{$\mathrm{Mg}$} & \multicolumn{2}{|c|}{$\mathrm{S}$} & \multicolumn{2}{|c|}{$\mathrm{Na}$} \\
\hline & Leaf & Grain & Leaf & Grain & Leaf & Grain & Leaf & Grain & Leaf & Grain & Leaf & Grain \\
\hline & \multicolumn{12}{|c|}{$\mathrm{mg} \cdot \mathrm{g}^{-1} \mathrm{DM}$} \\
\hline Apagbaala & $2.3 \mathrm{cB}$ & $4.6 \mathrm{cdA}$ & $15.7 \mathrm{ijA}$ & 12.9abB & $31.4 \mathrm{abA}$ & $0.73 \mathrm{aB}$ & 7.1abA & 1.6abcB & $2.8 \mathrm{bA}$ & 1.4abB & $387 \mathrm{fgA}$ & $12.0 \mathrm{bB}$ \\
\hline Bensogla & $3.7 \mathrm{abB}$ & $5.5 \mathrm{abA}$ & 20.3efA & $13.3 \mathrm{abB}$ & $24.5 \mathrm{deA}$ & $0.53 \mathrm{aB}$ & $6.5 \mathrm{abA}$ & $1.8 \mathrm{abB}$ & $4.7 \mathrm{aA}$ & $1.4 \mathrm{abB}$ & $1027 \mathrm{abA}$ & $17.0 \mathrm{bB}$ \\
\hline Botswana White & $3.5 \mathrm{abB}$ & 3.9ijA & $23.9 \mathrm{bcA}$ & 13.4abB & $24.2 \mathrm{deA}$ & $0.57 \mathrm{aB}$ & $5.5 \mathrm{abA}$ & $1.5 \mathrm{bcB}$ & $4.7 \mathrm{aA}$ & $1.2 \mathrm{bB}$ & $877 b c A$ & $36.3 \mathrm{bB}$ \\
\hline Brown Eye & 5.3abA & $4.5 \mathrm{deB}$ & $35.6 \mathrm{aA}$ & $12.9 \mathrm{abB}$ & 18.8hiA & $0.53 \mathrm{aB}$ & $4.5 \mathrm{bcA}$ & $1.6 a b c B$ & $3.5 \mathrm{abA}$ & $1.3 \mathrm{bB}$ & $337 \mathrm{fgA}$ & $16.0 \mathrm{bB}$ \\
\hline $\mathrm{CH} 14$ & $3.0 \mathrm{bB}$ & $3.8 \mathrm{jA}$ & $10.6 \mathrm{kB}$ & $11.7 \mathrm{bcA}$ & $34.9 \mathrm{aA}$ & $0.60 \mathrm{aB}$ & 8.4abA & $1.6 a b c B$ & 4.0abA & $1.3 \mathrm{bB}$ & $690 \mathrm{de} A$ & $37.3 \mathrm{bB}$ \\
\hline Fahari & 5.1abA & 4.0efB & $25.9 \mathrm{bcA}$ & 13.6abB & $16.9 \mathrm{ijA}$ & $0.40 \mathrm{aB}$ & $5.6 \mathrm{abA}$ & $1.7 \mathrm{abcB}$ & 3.6abA & $1.5 \mathrm{abB}$ & $913 \mathrm{bcA}$ & $28.7 \mathrm{bB}$ \\
\hline Glenda & 4.2abA & $4.5 \mathrm{de} \mathrm{A}$ & 29.6abA & $14.7 \mathrm{aB}$ & 17.0ijA & $1.13 \mathrm{aB}$ & $4.7 \mathrm{bcA}$ & $2.0 \mathrm{aB}$ & $4.7 \mathrm{aA}$ & $1.4 \mathrm{abB}$ & $560 \mathrm{de} A$ & $37.7 \mathrm{bB}$ \\
\hline Iron Grey & $5.7 \mathrm{abA}$ & $5.2 \mathrm{bcB}$ & $17.9 \mathrm{ghA}$ & 14.1abB & $23.8 \mathrm{deA}$ & $0.50 \mathrm{aB}$ & $6.7 \mathrm{abA}$ & 1.9abB & $2.7 \mathrm{bA}$ & $1.3 \mathrm{bB}$ & $1043 \mathrm{abA}$ & $26.7 \mathrm{bB}$ \\
\hline IT82D-889 & $3.8 \mathrm{abB}$ & 4.6deA & $21.2 \mathrm{deA}$ & 12.6abB & $24.7 \mathrm{deA}$ & $0.43 \mathrm{aB}$ & $5.4 \mathrm{abA}$ & 1.6abcB & 3.6abA & $1.3 \mathrm{bB}$ & $287 \mathrm{gA}$ & $19.3 \mathrm{bB}$ \\
\hline IT84S-2246 & $3.5 \mathrm{abB}$ & 4.1efA & 17.2hiA & $12.4 \mathrm{abB}$ & $23.8 \mathrm{deA}$ & $0.53 \mathrm{aB}$ & $5.4 \mathrm{abA}$ & $1.5 \mathrm{bcB}$ & 4.2abA & $1.3 \mathrm{bB}$ & $473 \mathrm{efA}$ & $26.0 \mathrm{bB}$ \\
\hline IT90K-59 & 4.2abA & $3.8 \mathrm{kB}$ & 29.7abA & $13.0 \mathrm{abB}$ & $15.2 \mathrm{jA}$ & $0.87 \mathrm{aB}$ & $4.5 \mathrm{bcA}$ & $1.8 \mathrm{abB}$ & 4.0abA & $1.3 \mathrm{bB}$ & $583 \mathrm{deA}$ & $29.0 \mathrm{bB}$ \\
\hline IT90K-76 & 5.0abA & $5.0 \mathrm{bcA}$ & 22.9deA & 13.6abB & $23.0 \mathrm{de} A$ & $0.83 \mathrm{aB}$ & $4.7 \mathrm{bcA}$ & $1.7 \mathrm{abcB}$ & $4.7 \mathrm{aA}$ & $1.4 \mathrm{abB}$ & $343 \mathrm{fgA}$ & $48.3 \mathrm{bB}$ \\
\hline IT93K-2045-29 & 4.5ab A & 4.1efB & $27.4 \mathrm{bcA}$ & $13.2 \mathrm{abB}$ & $23.5 \mathrm{deA}$ & $0.57 \mathrm{aB}$ & $5.4 \mathrm{abA}$ & $1.7 \mathrm{abcB}$ & $3.5 \mathrm{abA}$ & 1.4abB & $733 \mathrm{cdA}$ & $9.0 \mathrm{bB}$ \\
\hline IT93K-452-1 & $4.7 \mathrm{abA}$ & $4.5 \mathrm{deB}$ & $22.8 \mathrm{deA}$ & 13.9abB & $24.5 \mathrm{deA}$ & $0.53 \mathrm{aB}$ & 7.6abA & $1.7 \mathrm{abcB}$ & $3.7 \mathrm{abA}$ & $1.4 \mathrm{abB}$ & $840 \mathrm{bcA}$ & $17.7 \mathrm{bB}$ \\
\hline IT97K-499-39 & $3.2 \mathrm{bB}$ & 4.2efA & 16.9i A & $12.7 \mathrm{abB}$ & $20.9 \mathrm{fgA}$ & $0.50 \mathrm{aB}$ & $4.6 \mathrm{bcA}$ & $1.7 \mathrm{abcB}$ & $2.6 \mathrm{bA}$ & $1.3 \mathrm{bB}$ & $457 \mathrm{efA}$ & $32.3 \mathrm{bB}$ \\
\hline ITH98-20 & 4.6abB & $5.2 \mathrm{bcA}$ & $24.9 \mathrm{bcA}$ & $14.4 \mathrm{aB}$ & $27.7 \mathrm{bcA}$ & $0.83 \mathrm{aB}$ & $4.4 \mathrm{bcA}$ & $1.7 \mathrm{abcB}$ & 4.1abA & $1.6 \mathrm{aB}$ & 643deA & $105.3 \mathrm{aB}$ \\
\hline ITH98-46 & $3.4 \mathrm{bB}$ & $5.1 \mathrm{bcA}$ & $18.6 \mathrm{fgA}$ & $13.0 \mathrm{abB}$ & 33.0abA & $0.43 \mathrm{aB}$ & 7.8abA & $1.7 \mathrm{abcB}$ & $3.5 \mathrm{abA}$ & $1.3 \mathrm{bB}$ & $740 \mathrm{cdA}$ & $26.0 \mathrm{bB}$ \\
\hline Mamlaka & 3.6abB & 4.1efA & 23.3deA & 13.8abB & $24.3 \mathrm{deA}$ & $0.60 \mathrm{aB}$ & $4.6 \mathrm{bcA}$ & $1.8 \mathrm{abB}$ & 4.3abA & $1.3 \mathrm{bB}$ & $750 \mathrm{cdA}$ & $16.7 \mathrm{bB}$ \\
\hline Ngonji & $6.1 \mathrm{aA}$ & 4.6deB & $23.4 \mathrm{cdA}$ & $13.2 \mathrm{abB}$ & $20.2 \mathrm{ghA}$ & $0.50 \mathrm{aB}$ & $5.1 \mathrm{abA}$ & $1.8 \mathrm{abB}$ & 3.6abA & $1.3 \mathrm{bB}$ & $1290 \mathrm{aA}$ & $7.0 \mathrm{cB}$ \\
\hline Omondaw & $3.5 \mathrm{abB}$ & $5.5 \mathrm{bA}$ & 17.2hiA & $13.2 \mathrm{abB}$ & $27.7 \mathrm{bcA}$ & $0.40 \mathrm{aB}$ & 5.3abA & 1.9abB & 3.3abA & 1.4abB & $763 \mathrm{cdA}$ & $10.0 \mathrm{bcB}$ \\
\hline Pan 311 & $2.6 \mathrm{bB}$ & $4.4 \mathrm{de} \mathrm{A}$ & $16.1 \mathrm{jkA}$ & 13.3abB & $24.7 \mathrm{deA}$ & $0.70 \mathrm{aB}$ & $4.5 \mathrm{bcA}$ & 1.6abcB & $3.2 \mathrm{abA}$ & $1.3 \mathrm{bB}$ & $460 \mathrm{efA}$ & $34.0 \mathrm{bB}$ \\
\hline Sanzie & $4.5 \mathrm{abB}$ & $4.9 \mathrm{bcA}$ & $23.3 \mathrm{deA}$ & $12.5 \mathrm{bbB}$ & $22.9 \mathrm{de} A$ & $0.40 \mathrm{aB}$ & $4.3 \mathrm{bcA}$ & 1.9abB & 3.6abA & 1.4abB & $557 \mathrm{deA}$ & $18.7 \mathrm{bB}$ \\
\hline TVu11424 & 3.8abB & 4.1efA & $20.7 \mathrm{efA}$ & 13.9abB & $17.0 \mathrm{ijA}$ & $0.37 \mathrm{aB}$ & $4.8 \mathrm{bcA}$ & $1.8 \mathrm{abB}$ & $3.2 \mathrm{abA}$ & $1.5 \mathrm{abB}$ & $530 \mathrm{deA}$ & $45.7 \mathrm{bB}$ \\
\hline TVu1509 & 3.6abB & $6.2 \mathrm{aA}$ & $17.7 \mathrm{ghA}$ & 13.2abB & $26.6 \mathrm{cdA}$ & $0.60 \mathrm{aB}$ & 5.6abA & $1.5 \mathrm{bcB}$ & 3.2abA & $1.3 \mathrm{bB}$ & $733 \mathrm{cdA}$ & $30.3 \mathrm{bB}$ \\
\hline TVx3236 & $4.5 \mathrm{abB}$ & $5.0 \mathrm{bcA}$ & $22.8 \mathrm{deA}$ & $11.4 \mathrm{cB}$ & $26.0 \mathrm{de} A$ & $0.63 \mathrm{aB}$ & $5.7 \mathrm{abA}$ & $1.3 \mathrm{cB}$ & $3.2 \mathrm{abA}$ & $1.6 \mathrm{aB}$ & $870 \mathrm{bcA}$ & $38.7 \mathrm{bB}$ \\
\hline Vita 7 & 3.7abB & $5.0 \mathrm{bcA}$ & $23.2 \mathrm{deA}$ & 13.3abB & $22.6 \mathrm{deA}$ & $0.50 \mathrm{aB}$ & 5.4abA & $1.7 \mathrm{abcB}$ & 3.7abA & $1.2 \mathrm{cB}$ & $537 \mathrm{deA}$ & $11.7 \mathrm{bcB}$ \\
\hline Vuli-1 & $4.3 \mathrm{abB}$ & $4.7 \mathrm{cdA}$ & $25.5 \mathrm{bcA}$ & 13.9abB & 21.3ef A & $0.67 \mathrm{aB}$ & 5.1abA & $1.7 \mathrm{abcB}$ & 3.1abA & $1.4 \mathrm{abB}$ & $510 \mathrm{de} A$ & $14.3 \mathrm{bB}$ \\
\hline
\end{tabular}

39, TVu1509, IT84S-2246 and Iron Grey showing the least $\mathrm{K}$ levels in edible cowpea leaves (Table 1). Calcium concentration was highest in leaves of $\mathrm{CH} 14$, ITH98-46 and Apagbaala, followed by ITH98-20, Omondaw, TVu1509 and TVx3236, and lowest in IT90K-59, Fahari, Glenda, TVu11424 and Brown Eye. Leaf con- centration of $\mathrm{Mg}$ was greater in CH14, ITH98-46, IT93K452-1, Apagbaala and Iron Grey, and low in genotypes such as Sanzie, Pan 311 and Brown Eye (Table 1). With $\mathrm{S}$, Glenda and IT90K-76 showed the highest concentration in leaves, with the lowest recorded in IT97K499-39, Iron Grey and Apagbaala. However, Ngonji, Iron 
Grey, Bensogla and Fahari exhibited the highest concentration of $\mathrm{Na}$ in leaves, while IT82D-889, Brown Eye, IT90K-76 and Apagbaala showed the least (Table 1).

As found in 2005, there were again strong variations in macronutrients among the 15 cowpea genotypes tested in 2006. Cowpea genotypes Vuli-1, IT90K-59 and CH14 showed the highest $\mathrm{P}$ concentration in leaves, with IT97K-499-39, the lowest. Vuli-1 and IT93K-2045-29 again exhibited greater $\mathrm{K}$ in leaves, followed by TVu11424, Sanzie, CH14 and Glenda, while Soronko, Apagbaala, and IT97K-499-39 showed the least (Table 2). Calcium was higher in leaves of IT82D-899, IT93K2045-29 and Sanzie, and lowest in Vuli-1, Glenda, CH14 and IT97K-499-39 (Table 2). The concentration of Mg in the leaves was also much greater in Botswana White and Sanzie, followed by Soronko, IT97K-499-39, Apagbaala and IT90K-59, and lowest in TVu11424 and Vuli-1. No differences were found in leaf concentration of $\mathrm{S}$ in 2006. Vuli-1 and TVu11424 however showed the highest concentration of $\mathrm{Na}$ in edible leaves, followed by Brown Eye, CH14 and Sanzie, and least was in IT82D-889 and IT90K-59 (Table 2).

Trace element density also differed significantly $(\mathrm{P} \leq$
0.05 ) among the cowpea genotypes both in 2005 and 2006. As shown in Table 3, the highest concentration of $\mathrm{Fe}$ in cowpea leaves was observed in IT84S-2246, followed by IT93K-452-1 and Iron Grey, and lowest in Sanzie, Pan 311, TVu1509, Omondaw, ITH98-46 and Vita 7. Zinc density in cowpea leaves was also highest in IT84S-2246, followed by Bensogla, Glenda and TVu11424, and lowest in Vita 7, ITH98-46, Sanzie, TVx3236, Mamlaka, Ngonji and TVu1509 (Table 3). The concentration of $\mathrm{Mn}$ in edible leaves was found to be highest in IT90K-76, Botswana White, CH14 and IT84S-2246, and very low in IT93K-452-1, TVu1509, Sanzie and Vita 7. Similarly, $\mathrm{Cu}$ levels were very high in the leaves of TVu11424, Brown Eye, CH14, and IT82D-889, and low in IT90K-76, IT93K-2045-29, Sanzie, TVu1509 and Vita 7 (Table 3). The highest leaf concentration of B was recorded in cowpea genotypes Glenda, Sanzie, Brown Eye, Vuli-1, Botswana White, Bensogla, Omondaw and Iron Grey, while the lowest levels were found in Mamlaka and Vita 7 (Table 3).

As found in 2005, there were again strong differences in trace element density among the cowpea genotypes planted in 2006. Of the 15 genotypes tested, $\mathrm{CH} 14$ and

Table 2. A comparison of macro-element density among genotypes and between edible leaves and grain of field cowpea grown at Manga, Ghana, in 2006. The leaves were sampled at 46 DAP and grain harvested at 72 DAP. Mean with dissimilar letters in a column for each genotype (lower case) and in row for each macronutrient (upper case) are significantly different at $P \leq$ 0.05. Coefficient of variation ranged from 1 to 34.

\begin{tabular}{|c|c|c|c|c|c|c|c|c|c|c|c|c|}
\hline \multirow{2}{*}{ Genotype } & \multicolumn{2}{|c|}{$\mathrm{P}$} & \multicolumn{2}{|c|}{$\mathrm{K}$} & \multicolumn{2}{|c|}{$\mathrm{Ca}$} & \multicolumn{2}{|c|}{$\mathrm{Mg}$} & \multicolumn{2}{|c|}{$\mathrm{S}$} & \multicolumn{2}{|c|}{$\mathrm{Na}$} \\
\hline & Leaves & Grain & Leaves & Grain & Leaves & Grain & Leaves & Grain & Leaves & Grain & Leaves & Grain \\
\hline & \multicolumn{12}{|c|}{$\mathrm{mg} \cdot \mathrm{g}^{-1} \mathrm{DM}$} \\
\hline Apagbaala & $3.2 \mathrm{cdB}$ & $5.0 \mathrm{cdA}$ & $11.6 \mathrm{cB}$ & $14.1 \mathrm{bcA}$ & $49.5 \mathrm{bcA}$ & $1.1 \mathrm{aB}$ & 6.3abA & $1.9 \mathrm{bcB}$ & $2.4 \mathrm{aA}$ & $1.3 \mathrm{aB}$ & $418 \mathrm{cdA}$ & $35.7 \mathrm{defB}$ \\
\hline Botswana White & $4.1 \mathrm{bcB}$ & $4.7 \mathrm{dA}$ & $14.4 \mathrm{abA}$ & $14.0 \mathrm{bcB}$ & $47.6 \mathrm{bcA}$ & $1.0 \mathrm{aB}$ & $7.7 \mathrm{aA}$ & $1.9 \mathrm{cB}$ & $2.0 \mathrm{aA}$ & $1.2 \mathrm{aB}$ & $400 \mathrm{cdA}$ & $46.7 \mathrm{abB}$ \\
\hline Brown Eye & $3.3 \mathrm{cdB}$ & $4.7 \mathrm{dA}$ & 14.4abA & $13.5 \mathrm{cB}$ & $48.3 \mathrm{bcA}$ & $1.0 \mathrm{aB}$ & $5.5 \mathrm{bcA}$ & $2.0 \mathrm{bcB}$ & $2.1 \mathrm{aA}$ & $1.3 \mathrm{aB}$ & 578abA & 33.3efB \\
\hline $\mathrm{CH} 14$ & $4.6 \mathrm{bB}$ & $4.7 \mathrm{dA}$ & 16.2abA & $14.3 \mathrm{bcB}$ & $40.4 \mathrm{dA}$ & $1.0 \mathrm{aB}$ & $5.0 \mathrm{bcA}$ & 2.2abB & $1.8 \mathrm{aA}$ & $1.3 \mathrm{aB}$ & $573 \mathrm{abA}$ & 33.3efB \\
\hline Glenda & $4.1 \mathrm{bcB}$ & $4.9 \mathrm{cdA}$ & $16.0 \mathrm{abA}$ & $14.9 \mathrm{abB}$ & $40.2 \mathrm{dA}$ & $1.1 \mathrm{aB}$ & 6.1abA & $2.2 \mathrm{abB}$ & $2.4 \mathrm{aA}$ & $1.3 \mathrm{aB}$ & $492 \mathrm{bcA}$ & $31.3 \mathrm{fgB}$ \\
\hline IT82D-889 & $3.9 \mathrm{bcB}$ & $5.0 \mathrm{cdA}$ & 15.4abA & $13.5 \mathrm{cB}$ & $67.0 \mathrm{aA}$ & $0.8 \mathrm{aB}$ & $5.9 \mathrm{abA}$ & $1.9 \mathrm{bcB}$ & $2.3 \mathrm{aA}$ & $1.3 \mathrm{aB}$ & $238 \mathrm{dA}$ & $28.3 \mathrm{gB}$ \\
\hline IT84S-2246 & $3.7 \mathrm{bcB}$ & $4.9 \mathrm{cdA}$ & $15.6 \mathrm{abA}$ & $14.0 \mathrm{bcB}$ & $44.3 \mathrm{cA}$ & $1.0 \mathrm{aB}$ & $5.0 \mathrm{bcA}$ & $1.9 \mathrm{bcB}$ & $2.4 \mathrm{aA}$ & $1.3 \mathrm{aB}$ & $426 \mathrm{cdA}$ & $34.3 \mathrm{efB}$ \\
\hline IT90K-59 & $4.6 \mathrm{bcB}$ & $4.9 \mathrm{cdA}$ & 14.8abB & 15.1abA & $49.8 \mathrm{bcA}$ & $1.1 \mathrm{aB}$ & $6.2 \mathrm{abA}$ & $2.1 \mathrm{bcB}$ & $2.6 \mathrm{aA}$ & $1.3 \mathrm{aB}$ & $295 \mathrm{dA}$ & $40.0 \mathrm{cdB}$ \\
\hline IT93K-2045-29 & $4.2 \mathrm{bcB}$ & 5.4abA & $19.4 \mathrm{aA}$ & 15.1abB & $58.2 \mathrm{abA}$ & $1.0 \mathrm{aB}$ & 5.8abA & $2.1 \mathrm{bcB}$ & $2.5 \mathrm{aA}$ & $1.5 \mathrm{aB}$ & $448 \mathrm{cA}$ & $39.7 \mathrm{cdB}$ \\
\hline IT97K-499-39 & $3.0 \mathrm{~dB}$ & $5.5 \mathrm{abA}$ & $12.6 \mathrm{cB}$ & $14.7 \mathrm{bcA}$ & $40.4 \mathrm{dA}$ & $1.0 \mathrm{aB}$ & $6.4 \mathrm{abA}$ & $2.1 \mathrm{bcB}$ & $2.1 \mathrm{aA}$ & $1.4 \mathrm{aB}$ & $487 \mathrm{bcA}$ & $36.0 \mathrm{deB}$ \\
\hline ITH98-46 & $3.8 \mathrm{bcB}$ & $5.6 \mathrm{abA}$ & $13.7 \mathrm{bcB}$ & $14.5 \mathrm{bcA}$ & $43.5 \mathrm{cdA}$ & $1.0 \mathrm{aB}$ & $5.1 \mathrm{bcA}$ & $2.2 \mathrm{abB}$ & $1.9 \mathrm{aA}$ & $1.2 \mathrm{aB}$ & $473 \mathrm{bcA}$ & $37.7 \mathrm{deB}$ \\
\hline Sanzie & $3.9 \mathrm{bcB}$ & $5.9 \mathrm{aA}$ & 16.9abA & $14.9 \mathrm{abB}$ & $57.8 \mathrm{abA}$ & $1.1 \mathrm{aB}$ & $7.2 \mathrm{aA}$ & $2.4 \mathrm{aB}$ & $2.3 \mathrm{aA}$ & $1.3 \mathrm{aB}$ & $521 \mathrm{abA}$ & $20.3 \mathrm{hB}$ \\
\hline Soronko & $3.3 \mathrm{cdB}$ & $5.3 \mathrm{abcA}$ & $9.3 \mathrm{~dB}$ & $16.4 \mathrm{aA}$ & $46.2 \mathrm{bcA}$ & $1.0 \mathrm{aB}$ & $6.5 \mathrm{abA}$ & $2.4 \mathrm{aB}$ & $2.3 \mathrm{aA}$ & $1.5 \mathrm{aB}$ & $449 \mathrm{cA}$ & $42.7 \mathrm{bcB}$ \\
\hline TVu11424 & $3.7 \mathrm{bcB}$ & $4.7 \mathrm{dA}$ & 18.9abA & 15.3abB & $42.9 \mathrm{cdA}$ & $0.9 \mathrm{aB}$ & $4.6 \mathrm{cdA}$ & $2.1 \mathrm{bcB}$ & $1.8 \mathrm{aA}$ & $1.4 \mathrm{aB}$ & 666abA & $47.0 \mathrm{aB}$ \\
\hline Vuli-1 & $5.8 \mathrm{aA}$ & $5.0 \mathrm{cdA}$ & $19.1 \mathrm{aA}$ & $14.5 \mathrm{bcB}$ & $36.7 \mathrm{dA}$ & $1.1 \mathrm{aB}$ & $4.9 \mathrm{cdA}$ & $2.1 \mathrm{bcB}$ & $1.8 \mathrm{aA}$ & $1.4 \mathrm{aB}$ & $707 \mathrm{aA}$ & $34.7 \mathrm{efB}$ \\
\hline
\end{tabular}


Table 3. A comparison of micronutrient content among genotypes and between edible leaves and grain of field cowpea grown at Manga, Ghana, in 2005. The leaves were sampled at 46 DAP and grain harvested at 76 DAP. Mean with dissimilar letters in a column for each genotype (lower case) and in row for each macronutrient (upper case) are significantly different at $P \leq$ 0.05. Coefficient of variation ranged from 2 to 30.

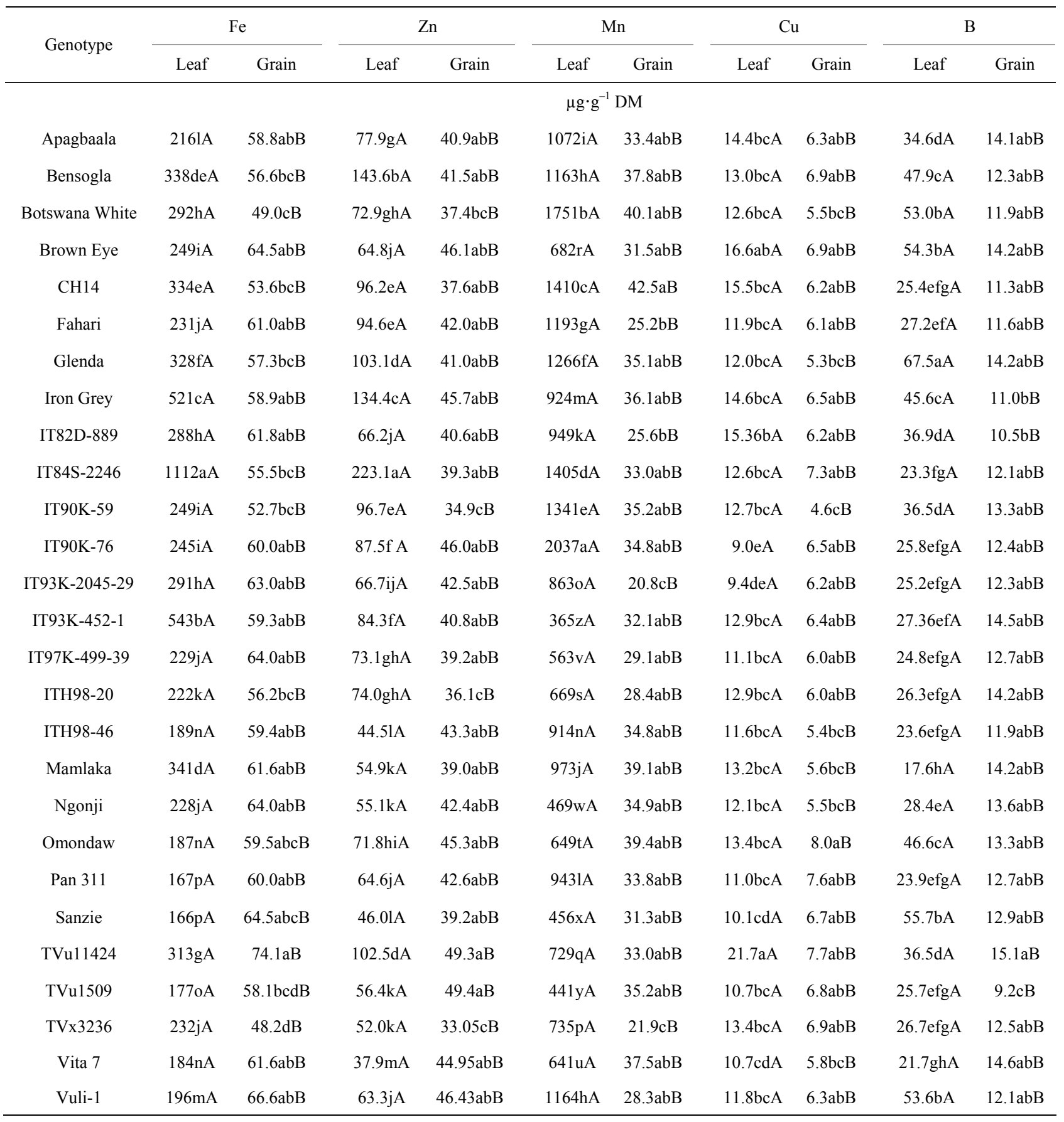

ITH98-46 showed the highest levels of Fe in leaves, followed by IT90K-59 and Soronko, and lowest in IT93K2045-29 (Table 4). Cowpea genotype CH14 was again highest in $\mathrm{Zn}$ concentration of leaves, followed by ITH98-46, Apagbaala, Soronko and IT90K-59, and lowest in IT93K-2045-29, Brown Eye, Sanzie, TVu11424, and Botswana White (Table 4). With Mn, Botswana White showed the highest concentration in cowpea leaves, followed by Vuli-1, Soronko, IT82D-889, Apagbaala, Sanzie, Brown Eye, IT82D-889 and ITH98-46, while the lowest was detected in IT93K-2045-29. The density of $\mathrm{Cu}$ in edible cowpea leaves was highest in Vuli-1 and 
Table 4. A comparison of micronutrient content among genotypes and between edible leaves and grain of field cowpea grown at Manga, Ghana, in 2006. The leaves were sampled at 46 DAP and grain harvested at 72 DAP. Mean with dissimilar letters in a column for each genotype (lower case) and in row for each macronutrient (upper case) are significantly different at $P \leq$ 0.05 . Coefficient of variation ranged from 2 to 30 .

\begin{tabular}{|c|c|c|c|c|c|c|c|c|c|c|}
\hline \multirow{2}{*}{ Genotype } & \multicolumn{2}{|c|}{$\mathrm{Fe}$} & \multicolumn{2}{|c|}{$\mathrm{Zn}$} & \multicolumn{2}{|c|}{$\mathrm{Mn}$} & \multicolumn{2}{|c|}{$\mathrm{Cu}$} & \multicolumn{2}{|c|}{ B } \\
\hline & Leaves & Grain & Leaves & Grain & Leaves & Grain & Leaves & Grain & Leaves & Grain \\
\hline & \multicolumn{10}{|c|}{$\mu g \cdot g^{-1} \mathrm{DM}$} \\
\hline Apagbaala & $484 \mathrm{bcA}$ & $53.2 \mathrm{fB}$ & $115.6 \mathrm{bcA}$ & $51.6 \mathrm{cB}$ & 1077.5abA & $34.5 \mathrm{eB}$ & $12.5 \mathrm{cdA}$ & $6.1 \mathrm{bcB}$ & 23.2abA & $13.5 \mathrm{~dB}$ \\
\hline Botswana White & $316 \mathrm{bcA}$ & $53.0 \mathrm{fB}$ & $76.9 \mathrm{cdA}$ & $44.1 \mathrm{~dB}$ & $1366.6 \mathrm{aA}$ & $33.2 \mathrm{fB}$ & $12.1 \mathrm{cdA}$ & $4.8 \mathrm{eB}$ & $18.0 \mathrm{cA}$ & $10.3 \mathrm{gB}$ \\
\hline Brown Eye & $335 \mathrm{bcA}$ & $59.8 \mathrm{deB}$ & $64.2 \mathrm{dA}$ & $46.7 \mathrm{deB}$ & $1044.0 \mathrm{abA}$ & $28.9 \mathrm{iB}$ & $14.7 \mathrm{abA}$ & $6.2 \mathrm{abB}$ & 23.9abA & $15.7 \mathrm{aB}$ \\
\hline CH14 & $1023 \mathrm{aA}$ & $61.8 \mathrm{~dB}$ & $169.6 \mathrm{aA}$ & $45.9 \mathrm{eB}$ & $757.1 \mathrm{cA}$ & $31.7 \mathrm{gB}$ & $13.9 \mathrm{bcA}$ & $5.6 \mathrm{~dB}$ & $22.3 \mathrm{bA}$ & $14.1 \mathrm{bcB}$ \\
\hline Glenda & $420 \mathrm{bcA}$ & $54.9 \mathrm{efB}$ & $89.1 \mathrm{cdA}$ & $44.2 \mathrm{~dB}$ & 1017.9abA & $35.7 \mathrm{~dB}$ & $13.6 \mathrm{bcA}$ & $5.0 \mathrm{eB}$ & $22.0 \mathrm{bA}$ & $13.9 \mathrm{cB}$ \\
\hline IT82D-889 & $409 \mathrm{bcA}$ & $38.9 \mathrm{gB}$ & $82.9 \mathrm{cdA}$ & $56.8 \mathrm{bB}$ & $1092.7 \mathrm{abA}$ & $36.8 \mathrm{cB}$ & $14.5 \mathrm{abA}$ & $5.9 \mathrm{bcB}$ & $24.1 \mathrm{abA}$ & $13.5 \mathrm{~dB}$ \\
\hline IT84S-2246 & $377 \mathrm{bcA}$ & $58.8 \mathrm{deB}$ & $82.8 \mathrm{cdA}$ & $47.1 \mathrm{deB}$ & $888.2 \mathrm{bcA}$ & $27.3 \mathrm{jB}$ & $15.6 \mathrm{aA}$ & $6.4 \mathrm{abB}$ & $26.4 \mathrm{aA}$ & $12.5 \mathrm{fB}$ \\
\hline IT90K-59 & $623 \mathrm{bA}$ & $53.4 \mathrm{fB}$ & $107.1 \mathrm{cdA}$ & $44.9 \mathrm{~dB}$ & $937.3 \mathrm{bcA}$ & $30.5 \mathrm{hB}$ & $14.7 \mathrm{abA}$ & $4.8 \mathrm{eB}$ & $22.2 \mathrm{bA}$ & $13.0 \mathrm{eB}$ \\
\hline IT93K-2045-29 & $240 \mathrm{cA}$ & $73.7 \mathrm{cB}$ & $62.1 \mathrm{dA}$ & $50.9 \mathrm{~dB}$ & $621.1 \mathrm{dA}$ & $27.5 \mathrm{jB}$ & $13.7 \mathrm{bcA}$ & $6.3 \mathrm{abB}$ & $22.2 \mathrm{bA}$ & $14.1 \mathrm{bcB}$ \\
\hline IT97K-499-39 & $407 \mathrm{bcA}$ & $76.6 \mathrm{cB}$ & $77.1 \mathrm{cdA}$ & 48.6deB & $928.6 \mathrm{bcA}$ & $28.5 \mathrm{iB}$ & $12.6 \mathrm{cdA}$ & $6.0 \mathrm{bcB}$ & 24.5abA & 12.6efB \\
\hline ITH98-46 & $996 \mathrm{aA}$ & $81.9 \mathrm{bB}$ & $157.5 \mathrm{abA}$ & $49.0 \mathrm{deB}$ & 1004.6abA & $36.4 \mathrm{cdB}$ & 14.3abA & $6.0 \mathrm{bcB}$ & 24.2abA & $12.7 \mathrm{efB}$ \\
\hline Sanzie & $315 \mathrm{bcA}$ & $56.0 \mathrm{efB}$ & $64.7 \mathrm{dA}$ & $45.7 \mathrm{eB}$ & 1028.2abA & $38.3 \mathrm{bB}$ & $13.9 \mathrm{bcA}$ & $5.8 \mathrm{bcB}$ & $23.7 \mathrm{abA}$ & $13.9 \mathrm{cB}$ \\
\hline Soronko & $592 \mathrm{bA}$ & $96.5 \mathrm{aB}$ & $107.1 \mathrm{cdA}$ & $65.4 \mathrm{aB}$ & $1105.0 \mathrm{abA}$ & $40.8 \mathrm{aB}$ & $12.1 \mathrm{cdA}$ & $6.6 \mathrm{aB}$ & $24.6 \mathrm{abA}$ & $14.4 \mathrm{bB}$ \\
\hline TVu11424 & $304 \mathrm{bcA}$ & $59.4 \mathrm{deB}$ & $69.3 \mathrm{cdA}$ & $46.9 \mathrm{deB}$ & $793.1 \mathrm{cA}$ & $31.2 \mathrm{ghB}$ & $13.9 \mathrm{bcA}$ & $5.6 \mathrm{cdB}$ & $26.1 \mathrm{aA}$ & $15.6 \mathrm{aB}$ \\
\hline Vuli-1 & $581 \mathrm{bcA}$ & $72.8 \mathrm{cB}$ & $117.8 \mathrm{bcA}$ & $56.4 \mathrm{bB}$ & $1184.0 \mathrm{abA}$ & $25.4 \mathrm{kB}$ & $16.3 \mathrm{aA}$ & $6.0 \mathrm{bcB}$ & 24.6abA & $13.7 \mathrm{cdB}$ \\
\hline
\end{tabular}

IT84S-2246, followed by IT90K-59, Brown Eye, IT82D889, and ITH98-46, and lowest in Botswana White, Soronko, Apagbaala and IT97K-499-39 (Table 4). With B, mineral density was highest in IT84S-2246 and TVu11424, and lowest in Botswana White, followed by CH14, Glenda, IT90k-59 and IT93K-2045-29 (Table 4).

\subsection{Trace Elements and Macronutrient Concentration in Cowpea Grain}

Analysis of cowpea grain for macro/micronutrients using inductively couple plasma mass spectrometry revealed marked differences among the different cowpea genotypes tested in 2005 and 2006 in the Sudano-sahelian savanna of Ghana. Of the 27 cowpea genotypes evaluated in 2005, the concentration of $\mathrm{P}$ was highest in the grain of TVu1509, Omondaw and Bensogla, and lowest in CH14, IT90K-59 and Botswana White (Table 1). Potassium density was also much greater in the grain of Glenda, ITH98-20 and Iron Grey, and lowest in TVx3236, CH14 and Sanzie (Table 1). The concentration of Mg was found to be highest in the grain of Glenda, Sanzie, Iron Grey, Omondaw, Mamlaka, Bensogla, and IT90K-
59, and lowest in TVx3236, TVu1509, IT84S-2246 and Botswana White. The density of $\mathrm{S}$ in cowpea grain was also much greater in TVx3236, ITH98-20, TVu11424 and Fahari, with the lowest being recorded in Vita 7, Botswana White, TVu1509 and Pan 311 (Table 1). With $\mathrm{Na}$, the highest concentration was found in only ITH9820, with the lowest levels obtained in Ngonji, IT93K2045-29, Omondaw, Vita 7 and Apagbaala (Table 1).

Similar variations in seed concentration of macronutrients were observed for the 15 cowpea genotypes in 2006. The level of $\mathrm{P}$ in cowpea grain was highest in three genotypes (namely, Sanzie, ITH98-46 and IT97K-49939), and lowest in Botswana White, Brown Eye, CH14, and TVu11424 (Table 2). However, the highest seed concentration of K was found in Soronko, TVu11424, IT93K-2045-29 and IT90K-59, with the lowest in Brown Eye and IT82D-889. With Mg, Sanzie and Soronko revealed the highest density in grain, while Apagbaala, Botswana White, IT82D-889 and IT84S-2246 showed the lowest (Table 2). Sodium concentrations were similarly highest in TVu11424 and Botswana White, and lowest in Sanzie and IT82D-889 (Table 2).

As with macronutrients, trace element density of cow- 
pea grain also differed among the cowpea genotypes tested in both 2005 and 2006. Of the 27 cowpea genotypes analyzed, $\mathrm{Fe}$ density was highest in the grain of TVu11424, Vuli-1, Sanzie, Brown Eye and IT97K-49939, and lowest in TVx3236 and Botswana White. The rest showed intermediate values. Zinc also showed its highest concentration in the grain of TVu1509, TVu11424 and Brown Eye, and the lowest in TVx3236 and IT90K-59 (Table 3). The concentration of Mn in cowpea grain was much higher in $\mathrm{CH} 14$ and Botswana White, and the lowest in IT93K-2045-29, TVx3236 and Fahari. Boron also showed its highest density in TVu11424 and Vita 7, and the lowest in TVu1509 and IT82D-889 (Table 3 ).

The genotypic differences in trace mineral density observed in 2006 were similar to those of 2005. As shown in Table 4, the highest concentration of $\mathrm{Fe}$ in cowpea grain was found in Soronko, ITH98-46, IT97K-499-39, IT93K-2045-29 and Vuli-1, while the lowest was detected in IT82D-889. The level of $\mathrm{Zn}$ in grain was highest in Soronko, IT82D-889, and Vuli-1, and lowest in Botswana White, Glenda, IT90K-59 and Sanzie (Table 4). The highest density of $\mathrm{Mn}$ in cowpea grain was again found in Soronko, followed by Sanzie, and lowest in $\mathrm{Vu}-$ li-1, IT84S-2246 and IT93K-2045-29 (Table 4). Highest concentration of $\mathrm{Cu}$ in cowpea grain was found in Soronko, followed by IT84S-2246 and IT93K-2045-29, and least in Botswana White and IT90K-59 (Table 4). The highest density of B in cowpea grain was found in Brown Eye and TVu11424, and lowest in Botswana White, IT84S-2246 and IT97K-499-39 (Table 4).

\subsection{Comparing Mineral Density in Edible Cowpea Leaves and Grain}

A comparison of macronutrients in edible cowpea leaves and grain showed huge differences in virtually all the mineral elements analyzed in both 2005 and 2006. As shown in Table 1, seven out of the 27 genotypes (namely, Brown Eye, Fahari, Iron Grey, IT90K-59, IT93K-204529, IT93K-452-1 and Ngonji) showed significantly higher concentrations of $\mathrm{P}$ in edible leaves over grain. Except for genotype $\mathrm{CH} 14$ (which exhibited lower K concentration in edible leaves), all the remaining 26 cowpea genotypes generally showed about 2-fold higher $\mathrm{K}$ concentration in leaves compared with grain (Table 1). In the case of $\mathrm{Ca}, \mathrm{Mg}, \mathrm{S}$ and $\mathrm{Na}$, all the 27 cowpea genotypes revealed many-fold higher concentrations in leaves when compared with grain (Table 1). The data for 2006 were similar in pattern, except for $\mathrm{P}$ which showed significantly greater levels in the grain of virtually all the cowpea genotypes when compared with their edible leaves (Table 2). Of the 15 cowpea genotypes tested in 2006, only Apagbaala, IT90K-59, IT97K-499-39, ITH98-
46 and Soronko showed lower K concentration in leaves relative to grain. The rest were higher in leaf $\mathrm{K}$ relative to grain (Table 2). As with the 2005 data for macronutrients, $\mathrm{Mg}, \mathrm{S}$ and $\mathrm{Na}$ again indicated greater concentrations in edible leaves relative to grain (Table 2).

The variations in trace mineral concentration between edible cowpea leaves and grain were very dramatic, especially for nutrients such as $\mathrm{Fe}$ and $\mathrm{Mn}$. As shown in Table 3, Fe, $\mathrm{Zn}, \mathrm{Mn}, \mathrm{Cu}$ and $\mathrm{B}$ all showed significantly high densities in edible leaves relative to grain, and exhibited respectively about 4, 2, 30, 2 and 3-fold more concentration in leaves than in grain. The data for 2006 again showed greater concentration of the trace elements $\mathrm{Fe}, \mathrm{Zn}, \mathrm{Mn}, \mathrm{Cu}$ and $\mathrm{B}$ in edible cowpea leaves compared with cowpea grain (Table 4).

\section{Discussion}

Cowpea is the most important source of plant protein and mineral nutrients for human nutrition and health in rural African children. Although a few studies have assessed the protein levels of edible cowpea leaves and grain [24-27], few (if any) have determined the mineral density of these organs as nutrient source. There is some evidence that nodulated legumes generally take up and accumulate more essential minerals in plant parts [12-15] than cereals, indicating that food legumes can biologically fortify their organs with dietarily important mineral nutrients needed for human nutrition and health. In some African countries like South Africa, cereal foods (e.g. maize and sorghum flour) are exogenously supplemented with trace elements such as $\mathrm{Fe}, \mathrm{Zn}$ and $\mathrm{Se}$ in order to overcome micronutrient deficiency in children [4-7]. In this study, 27 nodulated cowpea genotypes grown in the Sudano-Sahelian zone of Ghana showed marked variation in their ability to accumulate important mineral nutrients in edible plant parts. Not only did the 27 genotypes differ in their ability to absorb and accumulate minerals in their organs (Tables 1-4), they also showed markedly varied concentrations of trace elements and macronutrients in their edible leaves and grain (Tables 1-4), and exhibited significant changes in leaf mineral density with ontogeny.

What was important to note in this study is that not all cowpea varieties provide the same levels of mineral nutrients in leaves and/or grain for human consumption as food. For example, of the 27 cowpea genotypes planted in 2005, the macronutrient density of leaves in Iron Grey ( $\mathrm{P}, \mathrm{Mg}$, and $\mathrm{Na}$ ), Bensogla ( $\mathrm{Mg}, \mathrm{S}$ and $\mathrm{Na}$ ) and $\mathrm{CH} 14$ $(\mathrm{Ca}$ and $\mathrm{Mg}$ ) were much greater than the other genotypes. In 2006, IT93K-2045-29 and IT90K-59 were the only two out of 15 genotypes that showed higher accumulation of $\mathrm{P}, \mathrm{K}, \mathrm{Ca}$ and $\mathrm{Na}$ in both edible leaves and grain, while Sanzie exhibited greater $\mathrm{K}, \mathrm{Ca}, \mathrm{Mg}, \mathrm{S}$ and $\mathrm{Na}$ in 
leaves and $\mathrm{P}, \mathrm{K}$, and $\mathrm{Mg}$ in grain (Table 2). However, some genotypes accumulated more macronutrients in grain than edible leaves. Some examples include ITH9820 which had greater $\mathrm{P}, \mathrm{K}, \mathrm{Ca}$ and $\mathrm{Na}$ in grain in 2005 , $\mathrm{TVu} 11424$ with increased $\mathrm{Mg}, \mathrm{S}$ and $\mathrm{Na}$ in grain in 2005, and Soronko with greater $\mathrm{P}, \mathrm{K}, \mathrm{Mg}, \mathrm{S}$ and $\mathrm{Na}$ in grain but not leaves in 2006. Clearly, in terms of macronutrients, the nutrition and health benefits of edible leaves and grain differ depending on the choice of cowpea cultivar or variety.

A comparison of mineral levels in leaves and grain of cowpea showed that the former is a greater source of trace elements than the latter. In fact, trace element density was often 2- to 20-fold greater in leaves than in grain, indicating that cowpea leaves are a superior source of micronutrients for nutrition and human health than grain. More specifically, in 2005 Bensogla showed much greater concentrations of $\mathrm{Fe}, \mathrm{Zn}, \mathrm{Cu}$ and $\mathrm{B}$ in leaves with high levels of only $\mathrm{Cu}$ and $\mathrm{Mn}$ in grain; Iron Grey exhibited elevated levels of $\mathrm{Fe}, \mathrm{Zn}, \mathrm{Cu}$ and $\mathrm{B}$ in leaves and only $\mathrm{Zn}$ and $\mathrm{Mn}$ in grain; CH14 showed greater concentrations of $\mathrm{Fe}, \mathrm{Zn} \mathrm{Cu}$ and $\mathrm{Mn}$ in leaves and only $\mathrm{Mn}$ in grain, while IT84S-2246 had high concentrations of $\mathrm{Fe}$, $\mathrm{Zn}$ and $\mathrm{Mn}$ in leaves and $\mathrm{Cu}$ in grain (Table 3). Whereas some cowpea genotypes provided a balanced mix/concentration of nutrients in both edible leaves and grain, others showed greater concentration in only the grain. In 2005, TVu11424 was the best example of a genotype with elevated concentrations of $\mathrm{Fe}, \mathrm{Zn}, \mathrm{Cu}$ and $\mathrm{B}$ in both edible leaves and grain of cowpea (Table 3), while Brown Eye (Fe, Zn, Cu and B), Vita 7 (Fe, Zn, Mn and B) and Omondaw ( $\mathrm{Zn}, \mathrm{Cu}$ and $\mathrm{Mn}$ ) generally showed greater levels of the indicated micronutrients in their grain (Table 3). There was however another group of cowpea genotypes that was poor in mineral nutrient up- take and accumulation in organs. In 2005, for example, Pan311, IT97K-499-39 and IT93K-2045-29 showed very low concentrations of all trace elements and major nu- trients in both leaves and grain (Tables $\mathbf{1}$ and 3), indi- cating that while they may be high-yielding (e.g. Pan311), their leaves and grain are poor in nutritional quality. In another scenario, cowpea genotype ITH98-46 accumulated high levels of $\mathrm{P}, \mathrm{Ca}$ and $\mathrm{Mg}$ in its leaves in 2005, but exhibited the lowest concentrations of all trace elements in its leaves and grain during the same 2005. In terms of micronutrients, this again indicates a potentially low dietary value of the edible leaves and grain of genotype ITH98-46. In 2006, however, ITH98-46 together with Vuli-1 recorded the highest concentrations of $\mathrm{Fe}, \mathrm{Zn}$, $\mathrm{Cu}, \mathrm{Mn}$ and $\mathrm{B}$ in edible leaves, as well as $\mathrm{Fe}, \mathrm{Cu}$ and $\mathrm{Mn}$ in grain (Table 4). These variations in the mineral profile of cowpea leaves and grain between years could be attributed to soil factors, including moisture, available mineral $\mathrm{N}$ and quality and quantity of soil bacteria nodulating cowpea [28-30]. We have reported elsewhere that cowpea genotypes exhibit nodulation preferences for their microsymbionts even when planted in the same soil [31]. We have also shown that root-nodule bacterial strains can differ in their ability to induce mineral nutrient uptake by cowpea (T.I. Makhubedu, F. Pule-Meulenberg and F.D. Dakora, unpublished data). So, in addition to site effects, ineffective nodulation can reduce mineral density in cowpea relative to effective nodulation, and different cowpea/strain combinations can alter nutrient uptake in one genotype relative to another cowpea genotype.

Whatever the case, the data obtained in this study with some genotypes clearly show that food legumes can be bred or selected for enhanced mineral density in edible parts in order to improve human nutrition and health [8-10]. The inconsistencies in the mineral nutrient profile of any genotype between years, and possibly sites, could suggest that selection programs for increased mineral density should include the testing of different bacterial strains under controlled conditions for specific symbiotic compatibility in promoting increased nutrient uptake. That way, root-nodule bacterial strains can be identified that match host plants to increase mineral density in food legumes, especially trace elements, which are so much needed for child growth and human health [4,6-7].

Because anti-nutritional factors such as phytate and polyphenols commonly present in foods can make mineral nutrients biologically unavailable for absorption in humans [16-19], the levels of trace elements and macronutrients found in edible leaves and grain of cowpea in this study can only at best indicate the dietary potential of these organs as sources of mineral nutrients. Bioavailability studies are therefore needed to establish the contribution of cowpea leaves and grain towards meeting the dietary requirements of trace elements and macronutri- ents for human nutrition and health.

\section{Conclusion}

In conclusion, the mineral density of edible leaves and grain differed markedly among 27 cowpea genotypes. Leaf concentrations of macro/micronutrients were much greater in cowpea leaves up to flowering stage than close to physiological maturity. Interestingly, cowpea leaves accumulated higher macro/micronutrients than the grain. Taken together, our data suggest that cowpea genotypes can be selected (or bred) for high mineral accumulation for human nutrition and health. Given the high levels of micronutrients in cowpea, the inclusion of cowpea leaves in the diet of rural African communities could therefore be a cheap and sustainable way of overcoming trace element deficiency in children. 


\section{Acknowledgements}

We are grateful to the McKnight Foundation for the grant on South Africa Legumes Project, which supported this study as well as the student bursary of Alphonsus Belane. The National Research Foundation, Tshwane University of Technology, and the South African Research Chair on Agrochemurgy and Plant Symbioses are duly acknowledged for supporting the research of Felix Dakora.

\section{REFERENCES}

[1] P. A. Sanchez, A. M. N. Izac, I. Valencia and C. Pieri, "Soil Fertility Replenishment in Africa," In: S. A. Breth, Ed., Achieving Greater Impact from Research Investments in Africa, Sasakawa Africa Association, Mexico City, 1996.

[2] P. Drechel, D. Kunze and F. Penning de Vries, "Soil Nutrient Depletion and Population Growth in Sub-Saharan Africa: A Malthusian Nexus?" Population and Environment, Vol. 22, No. 4, 2001, pp. 411-423. doi:10.1023/A:1006701806772

[3] R. Lal, "Soil Degradation as a Reason for Inadequate Human Nutrition," Food Science, Vol. 1, No. 1, 2009, pp. 45-57. doi:10.1007/s12571-009-0009-Z

[4] U.E. MacIntyre, H. S. Kruger, C. S. Venter and H. H. Vorster, "Dietary Intakes of an African Population in Different Stages of Transition in the North West Province, South Africa: The THUSA Study," Nutrition Research, Vol. 22, No. 3, 2002, pp. 239-256.

[5] J. M. MacKeown, P. E. Cleaton-Jones and S. A. Norris, "Nutrient Intake among a Longitudinal Group of Urban Black South African Children at Four Interceptions between 1995 and 2000 (Birht-to-Ten Study)," Nutrition Research, Vol. 23, No. 2, 2003, pp. 185-197. doi:10.1016/S0271-5317(02)00489-X

[6] D. Labadarios, N. P. Steyn, C. Mgijima and N. Daldla, "Review of the South African Nutrition Policy 19942002 and Targets for 2007: Achievements and Challenges," Nutrition, Vol. 21, 2005, pp. 100-108. doi:10.1016/j.nut.2004.09.014

[7] H. C. Schönfeldt and N. Gibson, "Healthy Eating Guidelines in the South African Context," Journal of Food Composition and Analysis, Vol. 22, Suppl. 1, 2009, pp. S68-S73.

[8] R. D. Graham, D. Senadhira, S. Beebe, C. Iglesias and I. Montasterio, "Breeding for Micronutrient Density in Edible Portions of Staple Food Crops: Conventional Approaches," Field Crop Research, Vol. 60, No. 1, 1999, pp. 57-80. doi:10.1016/S0378-4290(98)00133-6

[9] R. M. Welch and R. D. Graham, "Breeding Crops for Enhanced Micronutrient Content," Trend in Food Science and Technology, Vol. 245, No. 1, 2002, pp. 191-209.

[10] H. E. Bouis, "Micronutrient Fortification of Plants through Plant Breeding: Can It Improve Nutrition in Man at Low Cost?" Proceedings of Nutritional Society, Vol. 62, No. 2, 2003, pp. 403-411. doi:10.1079/PNS2003262
[11] M. B. Zimmermann and R. F. Hurrell, "Improving Iron, Zinc and Vitamin A Nutrition through Plant Biotechnology," Current Opinion in Biotechnology, Vol. 13, No. 2, 2002, pp. 142-145. doi:10.1016/S0958-1669(02)00304-X

[12] J. Kubota, "Copper Status of United States Soils and Forage Plants," Agronomy Journal, Vol. 75, 1983, pp. 109-119. doi:10.2134/agronj1983.00021962007500060014x

[13] G. A. Pedersen, G. E. Brink and T. E. Fairbrother, "Nutrient Uptake in Plant Parts of Sixteen Forage Fertilized with Poultry Litter: Nitrogen, Phosphorus, Potassium, Copper and Zinc," Agronomy Journal, Vol. 94, No. 4, 2002, pp. 895-904.

[14] M. R. Broadley, H. C. Bowen, H. L. Cotterill, J. P. Hammond, M. C. Meacham, A. Mead and P. J. White, "Variation in the Shoot Calcium Content of Angiosperms," Journal of Experimental Botany, Vol. 54, No. 368, 2003, pp. 1431-1446. doi:10.1093/jxb/erg143

[15] N. K. Fageria, "Dry Matter Yield and Shoot Nutrient Concentration of Upland Rice, Common Bean, Corn, and Soybean Grown in Rotation on an Oxisol," Communication in Soil Science and Plant Analysis, Vol. 35, 2004, pp. 961-964. doi:10.1081/CSS-120030572

[16] R. S. Gibson, "Technological Approaches to Combating Iron Deficiency," European Journal of Clinical Nutrition, Vol. 51, 1997, p. S27.

[17] B. Mulvihill and P. A. Morrissey, "An Investigation of Factors Influencing the Bioavailability of Non-Haem Iron from Meat Systems," Irish Journal of Agriculture and Food Research, Vol. 37, 1998, pp. 219-226.

[18] E. Forssard, M. Bucher, F. Machler, A. Mozafar and R. Hurrell, "Potential for Increasing the Content and Bioavialability of $\mathrm{Fe}, \mathrm{Zn}$, and $\mathrm{Ca}$ in Plants for Human Nutrition," Journal of Science, Food and Agriculture, Vol. 80, No. 7, 2000, pp. 861-879. doi:10.1002/(SICI)1097-0010(20000515)80:7<861::AIDJSFA601>3.0.CO;2-P

[19] R. M. Welch and R. D. Graham, "Agriculture: The Real Nexus for Enhancing Bioavailable Micronutrients in Food Crops," Journal of Trace Elements in Medicine and Biology, Vol. 18, 2005, pp. 299-307. doi:10.1016/j.jtemb.2005.03.001

[20] Food and Agriculture Organization FAO, "FAOUNESCO Soil Map of the World, World Soil Resource Rome," Food and Agriculture Organization, Rome, Report 60, 1990.

[21] A. Ataro, R. I. McCrindle, B. M. Botha, C. M. E. McCrindle and P. P. Ndibewu, "Quantification of Trace Elements in Raw Cow's Milk by Inductively Coupled Plasma Mass Spectrometry (ICP-MS)," Food Chemistry, Vol. 111, No. 1, 2008, pp. 243-248. doi:10.1016/i.foodchem.2008.03.056

[22] Fertilizer Society of South Africa FSSA, "Manual of Soil Analysis Methods," Fertilizer Society of South Africa, South Africa Pretoria, 1974, p. 37.

[23] StatSoft Inc., "STATISTICA Data Analysis Software System, Version 7.1," 2005. http://www.statsoft.com 
[24] R. Bressani, "Nutritive Value of Cowpea," In: S. R. Singh and R. O. Rachie, Eds., Cowpea Research, Production and Utilization, Wiley, Winchester, 1985, pp. 353-359.

[25] S. S. Nielsen, T. A. Ohler and C. A. Mitchell, "Cowpea Leaves for Human Consumption: Production, Utilization and Nutrient Composition," In: B. B. Singh, R. A. J. Moham, K. E. Dashiell and L. E. N. Jackai, Eds., Advances in Cowpea Research, International Institute of Tropical Agriculture, IITA, Nigeria, Ibadan, 1997, pp. 326-332.

[26] B. C. Donovan, M. A. McNiven, J. A. McLeod and D. M. Anderson, "Protein Quality of Two Cultivars of Lupin Seeds Evaluated in Weaning Rats," Animal Feed Science and Technology, Vol. 33, No. 1-2, 1991, pp. 87-95. doi:10.1016/0377-8401(91)90048-W

[27] F. J. Nell, F. K. Siebrits and J. P. Hayes, "Studies on the Nutritive Value of Cowpeas (Vigna unguiculata)," South African Journal of Animal Science Vol. 22, 1992, pp. 157-160.

[28] K. K. Ayisi, R. J. Nkgapele and F. D. Dakora, "Nodule
Formation and Function in Six Varieties of Cowpea ( Vigna unguiculata L. Walp) Grown in a Nitrogen-Rich Field Soil in South Africa," Symbiosis, Vol. 28, 2000, pp. 17-31.

[29] F. Kurdali, F. Al-Ain and M. Al-Shamma. "Nodulation, Dry Matter Production, and $\mathrm{N}_{2}$ Fixation by Fababean and Chickpea as Affected by Soil Moisture and Potassium Fertilizer," Journal of Plant Nutrition, Vol. 25, No. 2, 2002, pp. 355-368. doi:10.1081/PLN-100108841

[30] R. C. Abaidoo, H. H. Keyser, P. W. Singleton, K. E. Dashiell and N. Sanginga, "Population Size, Distribution, and Symbiotic Characteristics of Indigenous Bradyrhizobium sp. That nodulate TGx Soybean Genotypes in Africa," Applied Soil Ecology, Vol. 35, No. 1, 2007, pp. 57-67. doi:10.1016/j.apsoil.2006.05.006

[31] F. Pule-Meulenberg, C. Gyogluu, J. B. Naab and F. D. Dakora, "Symbiotic N Nutrition, Bradyrhizobial Biodiversity and Photosynthetic Functioning of Six Inoculated Promiscuous-Nodulating Soybean Genotypes," Journal of Plant Physiology, Vol. 168, No. 6, 2011, pp. 540-548. doi:10.1016/j.jplph.2010.08.019 